\title{
A STUDY ON THE EFFECT OF INJECTIONS OF BRAIN AND LIVER ON SPERMATOGENESIS IN GUINEA-PIGS
}

\author{
A. A. ETRIBI, K. ZAKI AND W. ABOUL FADLE* \\ Department of Male Sterility, Sexology and Venerology, \\ Faculty of Medicine, Cairo University, Egypt, U.A.R.
}

(Received 23rd September 1970)

\begin{abstract}
Summary. The injection of homologous brain tissue with adjuvant into guinea-pigs resulted in varying degrees of aspermatogenesis, without the development of encephalomyelitis. There was a moderate degree of germinal cell damage in $50 \%$, and a severe degree in $30 \%$ of animals.

Cross-reactivity was demonstrated between guinea-pig brain and testis antisera.

Liver tissue in adjuvant did not induce germinal cell damage and never evoked an immunological response.
\end{abstract}

\section{INTRODUGTION}

Different authors have induced aspermatogenesis in guinea-pigs by the injection of various types of tissue suspension. Testicular homogenate obtained with adjuvant has been found to be effective in arresting the spermatogenic process in guinea-pigs (Freund \& Lipton, 1953; Freund, Lipton \& Thompson, 1954; Katsh, 1958, Laurence \& Perlbachs, 1962; Zaki, 1968). Injections of homologous spermatozoa have also been found to be successful in inhibiting spermatogenesis (Kennedy, 1924; Oslund, 1926). Liver homogenate in adjuvant, however, failed to inhibit spermatogenesis (Mudd \& Mudd, 1929; Freund \& Lipton, 1953), while brain tissue was effective in producing germinal cell damage (Freund \& Lipton, 1953; Freund et al., 1954).

The aim of this work was to investigate the effect of injections of brain and liver homogenate on spermatogenesis in the guinea-pig.

\section{MATERIALS AND METHODS}

Forty, mature, healthy male guinea-pigs of the English out-bred strain were divided into four groups of ten animals each. Group A was given $300 \mathrm{mg}$ homologous brain homogenate in $0.7 \mathrm{ml}$ complete Freund's adjuvant. Group B received $300 \mathrm{mg}$ homologous liver suspension in $0.7 \mathrm{ml}$ complete Freund's adjuvant. Group $\mathrm{C}$ and Group $\mathrm{D}$ comprised the control animals which received $0.7 \mathrm{ml}$ bland complete Freund's adjuvant and $0.7 \mathrm{ml}$ bland saline per animal,

\footnotetext{
- Present address: Department of Obstetrics, Gynaecology and A.I., Faculty of Veterinary Medicine, Gairo University.
} 
respectively. The antigenic material was prepared in the manner described by Zaki (1968). The brain and liver were minced and then homogenized in Ten Broeck grinders with equal volumes of distilled water containing $0.25 \%$ phenol $(\mathrm{w} / \mathrm{v})$. The tissues were further homogenized at $5000 \mathrm{rev} / \mathrm{min}$ in a centrifuge for $15 \mathrm{~min}$ and then mixed with the complete Freund's adjuvant in the abovementioned proportions. These preparations were either used immediately or stored at -10 to $-20^{\circ} \mathrm{C}$. Injections were repeated at 0,7 and 21 days. Testicular biopsies and blood samples were taken at the start of the experiment. Animals were killed 35 days after the start of the experiment and blood and testicular samples were taken. Immobilization and agglutination tests were performed according to Quinlivan (1966).

The following reactions were performed with guinea-pig antiserum and fresh semen obtained within $1 \mathrm{hr}$ of the test.

\section{Immobilization test}

In a Kahn tube, $0.05 \mathrm{ml}$ of fresh semen was mixed with $0.25 \mathrm{ml}$ of guinea-pig antiserum and $0.25 \mathrm{ml}$ of isotonic saline. The mixture was maintained at room temperature and $0.05 \mathrm{ml}$ was removed for microscopic examination every $20 \mathrm{~min}$ for $2 \mathrm{hr}$. At every examination, 100 spermatozoa were counted in order to determine the percentage that was non-motile.

\section{Agglutination tests}

In a Kahn tube, $0.05 \mathrm{ml}$ of fresh semen was mixed with $0.5 \mathrm{ml}$ of full strength guinea-pig antiserum and $0.5 \mathrm{ml}$ of dilutions of antiserum in saline varying from $1: 4,1: 8$, etc. and then incubated in a water bath at $37^{\circ} \mathrm{C}$ for $4 \mathrm{hr}$. Subsequently, $0.05 \mathrm{ml}$ of the mixture was removed by micropipette, placed on a slide with a cover slip and examined microscopically at $\frac{1}{2}, 1,2$ and $4 \mathrm{hr}$. The diagnosis of a t ve reaction required the presence of motile agglutinated spermatozoa and no dead cells or débris.

The rating of the testicular biopsies followed that adopted by Freund $e t$ al. (1954). Damage was graded as follows:

$1+$, very few mature spermatozoa present, swelling and vacuolization of few of the spermatogenic cells, some of these being exfoliated.

$2+$, may or may not show a few mature spermatozoa, swelling, vacuolization, and exfoliation of fairly large numbers of spermatogenic cells.

$3+$, no mature spermatozoa present, swelling, vacuolization, and exfoliation of a large number of spermatogenic cells.

$4+$, damage ranging from partial to complete devastation of the tubules, with only Sertoli cells and the basement membrane remaining.

\section{RESULTS}

Only the brain tissue injections affected spermatogenesis and then only to a variable extent, but antibodies were produced which yielded positive immobilization and agglutination tests against homologous epididymal spermatozoa. The titres varied between $1 / 64$ and $1 / 256$. 


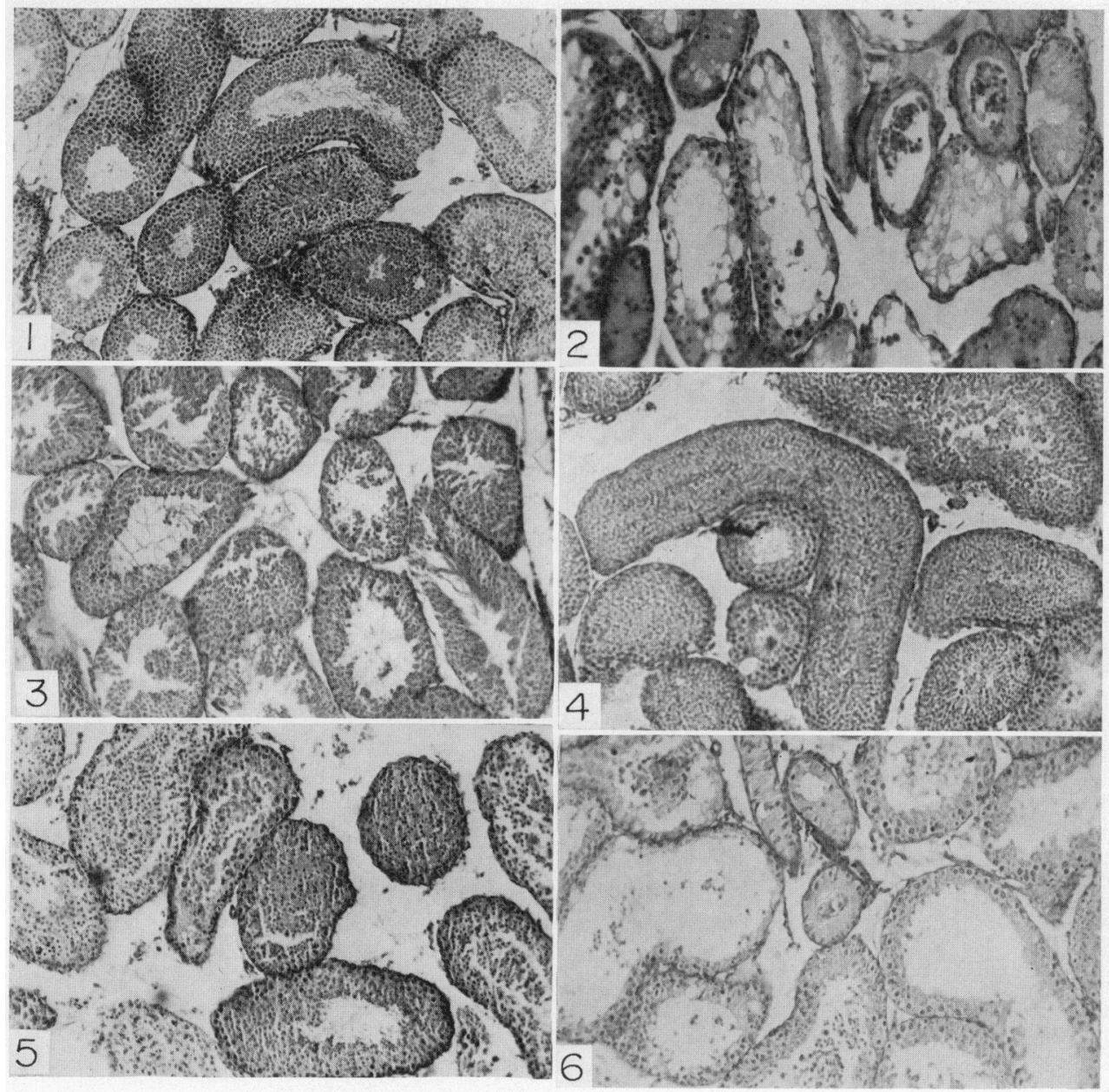

FIr. 1. Normal testicular biopsy after liver injection. $\times 25$.

Fri. 2. Germinal cell damage of Grade 4. $\times 25$.

Fic;. 3. Normal testicular biopsy of control animals. $\times 2.5$.

Fir: 4. Germinal cell damagc of Grade $1+. \times 2.5$.

Fici. 5. Germinal cell damage of Grade $2+. \times 25$.

Iitt. 6. Germinal cell damage of Grade $3+. \times 25$.

(Facing p. 334) 
Liver tissue in adjuvant (Group B), bland adjuvant (Group $G$ ) and saline (Group D) produced neither testicular damage nor serological response.

While the testicular biopsies of animals injected with liver did not show any lesion (Pl. 1, Fig. 1), the group given brain tissue showed definite damage (Pl. 1, Fig. 2). Animals in the control groups did not show any testicular lesion (Pl. 1, Fig. 3).

TABLE 1

GERMINAL LESIONS AND SPERM-AGGLUTINATION AND IMMOBILIZATION TITRES IN THE SERA OF THE MALE GUINEA-PIGS INJECTED WITH BRAIN HOMOGENATE IN COMPLETE FREUND'S ADJUVANT (GROUP A)

\begin{tabular}{c|c|c|c|cc}
\hline $\begin{array}{c}\text { Animal } \\
\text { serial } \\
\text { no. }\end{array}$ & $\begin{array}{c}\text { Body wt } \\
(\mathrm{g})\end{array}$ & $\begin{array}{c}\text { Degree of } \\
\text { germinal cell } \\
\text { lesion }\end{array}$ & $\begin{array}{c}\text { Sera obtained } \\
\text { before } \\
\text { injection }\end{array}$ & \multicolumn{2}{|c}{$\begin{array}{c}\text { Sera obtained } \\
\text { after } \\
\text { injection }\end{array}$} \\
\cline { 3 - 5 } & & & Agglutination & Immobilization & Agglutination \\
\hline 1 & 380 & $4+$ & 0 & $1 / 128$ & $1 / 250$ \\
2 & 370 & $4+$ & 0 & $1 / 128$ & $1 / 128$ \\
3 & 380 & $4+$ & 0 & $1 / 128$ & $1 / 128$ \\
4 & 400 & $3+$ & $<1 / 16$ & $1 / 64$ & $1 / 128$ \\
5 & 440 & $2+$ & 0 & $1 / 128$ & $1 / 128$ \\
6 & 400 & $2+$ & 0 & $1 / 64$ & $1 / 64$ \\
7 & 500 & $2+$ & $<1 / 16$ & $1 / 128$ & $1 / 128$ \\
8 & 460 & $1+$ & $1 / 16$ & $1 / 64$ & $1 / 128$ \\
9 & 500 & $1+$ & 0 & $1 / 64$ & $1 / 64$ \\
10 & 390 & $3+$ & 0 & $1 / 128$ & $1 / 128$ \\
\hline
\end{tabular}

As illustrated in Table 1, all grades of testicular damage were recorded, ranging from $1+(\mathrm{Pl} .1$, Fig. 4) in two animals to $4+$ (Pl. 1, Fig. 2) in three animals. The damage was evidently correlated with body weight, animals with a higher body weight developing a milder lesion. Moderate damage of $2+$ (Pl. 1, Fig. 5) and 3+ (Pl. 1, Fig. 6) was detected in five animals.

All the animals in Group A remained clinically normal throughout the test period and none developed encephalomyelitis.

\section{DISCUSSION}

It has been shown (Zaki, 1968) that injections of homologous testicular tissue and spermatozoa are effective in producing germinal cell damage. Although Freund \& Lipton (1953) reported the incidence of allergic encephalomyelitis in animals given brain tissue, no such case developed in the present series, as judged by the onset of loss of weight, paralysis or death.

The finding that brain tissue in adjuvant was as effective as testicular tissue in producing a germinal cell lesion was in agreement with the results of Zaki (1968).

Brain tissue provoked the appearance of antibodies, both immobilizins and agglutinins, in rather high titres but generally lower than those produced by testicular tissue. Liver substance in adjuvant did not alter the serological state of the animal. Sera obtained against brain tissue reacted against homologous 
epididymal spermatozoa which in turn were reported to react with anti-testis sera (Lewis, 1934, 1941; Freund \& Lipton, 1953; Katsh, 1959). Katsh (1959) could inhibit fertility in female guinea-pigs by injecting homologous brain tissue in adjuvant.

In conclusion, it may be stated that the testis antigens showed tissue specificity and cross-reacted selectively with brain antigens.

\section{REFERENCES}

FreUnd, J. \& LIPTON, M. M. (1953) The efficacy of the intracutaneous route of infection and susceptibility of the Hartley strain of guinea pigs in experimental allergic encephalitis. 7 . Immun. 70, 326.

Freund, J., Lipton, M. M. \& Thompson, G. E. (1954) Impairment of spermatogenesis in the rat after cutaneous injection of testicular suspension and adjuvant. Proc. Soc. exp. Biol. Med. 87, 408.

KATSH, S. (1958) In vitro anaphylactic and nonanaphylactic responses of organs of immunized guinea pigs. F. Pharmac. exp. Ther. 124, 86.

KATsh, S. (1959) Immunology, fertility and infertility. A historical survey. Am. F. Obstet. Gynec. 77, 946.

Kennedy, W. P. (1924) The production of spermatoxins. Q. Fl exp. Physiol. 14, 279.

Laurence, K. A. \& Perlbachs, M. (1962) Studies on the relationship of delayed hypersensitivity to experimental aspermatogenesis in rats. Bact. Proc. 88.

Lewis, J. H. (1934) The antigenic relationship of the alcohol soluble fractions of brain and testicle. $\mathcal{F}$. Immun. 27, 473.

LEwis, J. H. (1941) The antigenic relationship of alcohol soluble substances of corpus luteum to those of testis and brain. Am. F. Path. 17, 725.

Mudd, S. N. \& MUdD, E. B. H. (1929) The specificity of mammalian spermatozoa, with special reference to electrophoresis as a means of serological differentiation. .7. Immun. 17, 39.

Oslund, R. N. (1926) Physiological effects of spermatoxins. 7. Am. med. Ass. 86, 1755.

QuinLIVAN, W. L. G. (1966) Antigen-antibody reaction with human semen. Fert. Steril. 17, 722.

ZAKI, K. (1968) Immunological aspermatogenesis induced in guinea-pigs. M.D. thesis, Cairo University. 